\title{
MALACHITE GREEN REMOVAL AND BIOELECTRICITY GENERATION USING A NOVEL DESIGN MULTI-ELECTRODE MICROBIAL FUEL CELL
}

\author{
Pimprapa Chaijak \\ Microbial Fuel Cell \& Bioremediation Laboratory, Department of Biology, Faculty of Science, Thaksin University 93210, Thailand, \\ e-mail:chaijak.pimprapa@gmail.com
}

\begin{abstract}
Aim of the study

Malachite green (MG) is a well-known synthetic dye, which is used as liquid pharmaceutical to improve the problem of protozoan and fungal diseases. MG can be fermented to harmful carcinogen, leuco-malachite green, when discharged to water stream by normal flora.
\end{abstract}

\section{Material and methods}

In this study, a novel-design microbial fuel cell (MFC) was developed, and reported to remove the MG by immobilizing the laccase-producing yeast Galactomycess reessii onto the anode electrode.

\begin{abstract}
Results and conclusions
In our study results, we have demonstrated that it successfully removed the MG in $98.15 \pm 0.92 \%$ within 1 day of operation, while by direct inoculation it is possible to remove $88.93 \pm 1.00 \%$ after 5 days. Moreover, the open circuit voltage (OCV), current density (CD), and power density (PD) of $550.00 \pm 10.00 \%, 3.90$ $\pm 0.10 \mathrm{~A} / \mathrm{m}^{3}$ and $1.52 \pm 0.08 \mathrm{~W} / \mathrm{m}^{3}$ were achieved. The study demonstrates that the novel-design MFC has great potential for MG removal and bioelectricity generation. The present work is the first report of using termite-associated yeast to decolourise a synthetic dye.
\end{abstract}

Keywords: Carcinogen, Yeast, Oxidoreductase, Laccase, Microbial fuel cell

\section{Introduction}

Laccase (EC 1.10.3.2) is a well-known multi-copper oxidase enzyme, containing oxidoreductase that is industrially important and environmentally friendly. Laccase has broad substrate specificity and can degrade or polymerize various types of phenolic compounds - such as synthetic dye - by reduction of atmospheric oxygen gas $\left(\mathrm{O}_{2}\right)$ to pure water $\left(\mathrm{H}_{2} \mathrm{O}\right)$. Laccases have been applied in different industries such as food, bioremediation, textile, biofuel, and other fields. Having said that, the use of laccase is limited by high cost of production and recovery, and by the fact that it is sensitive to inhibition of enzymes under industrial conditions. Lack of stability because of activity loss is another factor limiting a possible scale-up (Ba et al., 2013; Fernandez et al., 2013; Asgher et al., 2014; Kudanga and Le Rose-Hill, 2014; Pezzella et al., 2015; Yang et al., 2017).

Native termites and their microbes are spread throughout the broad area of both African and Asian continents, because these areas are rich in high-potential soil invertebrates (Taprab et al., 2002; Senanayake et al., 2016). Termite-associated microbes secrete the

凶e-mail: chaijak.pimprapa@gmail.com 
lignocellulolytic enzymes for wood decaying for termite nutrition and orientation to food materials (Cornelius et al., 2002). These microbes can degrade the composition of the biomass substrate to insect feeding and detoxify the toxic compound, such as lignin present in plant tissues, through the action of lignin degrading enzyme like extracellular laccase (Chaijak et al., 2017; Senanayake et al., 2016).

Malachite green (MG) is the member of triphenylmethane dyes that are typically applied in aquaculture to inhibit the growth of fish pathogens like protozoa and fungi. Moreover, this colouring is commonly used in food, pharmaceutical, and textile industries. Typically, the MG is absorbed by fish and converted to the form of leuco-malachite green, which is a colourless and harmful metabolite, and this metabolite is stored in the fish tissue (Bergwerff and Scherpenisse, 2003; Srivastava et al., 2004; Zhang et al., 2013). The MG has broad toxicity spectrum in both prokaryotes and eukaryotes. Its harmful effects include tissue damage, growth and reproductive system inhibition, inducing the abnormal development and high carcinogenic potential (Cha et al., 2001; Srivastava et al., 2004). Additionally, this toxic dye effluent can be spread into ground water and be expended for agriculture, thus disturbing soil and fertility (Kalyani et al., 2008). Nowadays, the bioremediation of malachite green is carried out by using the pure fungal laccase, both in the form of the immobilized enzyme and free enzyme but this system is very costly to operate, and furthermore it is sensitive to environmental changes (Yang et al., 2015).

Microbial fuel cell (MFC) is a well-known device in an area of wastewater treatment and electricity generation. In a MFC, the substrate such as xenobiotic is degraded by an electron that releases microbes - an exoelectrogen. Then, both electron and proton are transferred to cathode chamber, the electric power is produced, and the contaminated substrate is degraded (Rozendal et al., 2008).

The termite-associated yeast Galactomyces reessii has been shown to provide high laccase yield and strong decolourisation in field studies of industrial wastewater (Chaijak et al., 2018). In this study, this yeast was used for the removal of the MG from the aquatic pharmaceutical, using its laccase activity. The novel design of MFC was used for malachite green removal and electricity generation.

\section{MATERIAL AND METHODS}

\section{Microbe and Culture Conditions}

The G. reessii (accession number: MF 278649.1) (see: Fig. 1), a laccase producing yeast was used for the degradation and decolourisation of malachite green. The G. reessii was maintained on potato dextrose agar (Sigma-Aldrich, United States) at $4.0 \pm 1.0^{\circ} \mathrm{C}$. The stock MG solution (Sigma-Aldrich, United States) was prepared at a concentration of $1.0 \mathrm{mg} / \mathrm{mL}$ in sterile deionized water, then filtered through the Whatman no.1 filter paper (11 $\mu \mathrm{m}$ diameter, Sigma-Aldrich, United States) and stored at $4.0 \pm 1.0^{\circ} \mathrm{C}$ until used (Yang et al., 2015).

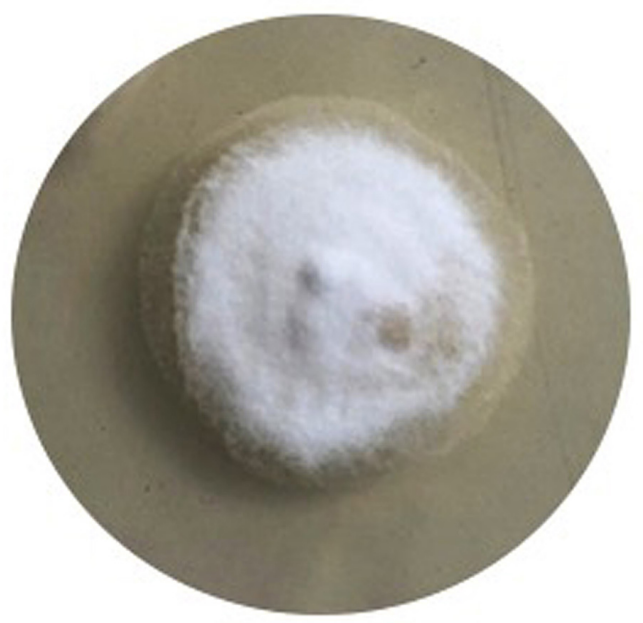

Fig 1. Colony of termite associated yeast G. reessii on PDA after 5-days incubation at $30.0 \pm 1.0{ }^{\circ} \mathrm{C}$

\section{In vitro $\mathrm{mg}$ removal}

The 5-days old $G$. reessii agar plug $(1.0 \mathrm{~cm}$ diameter) was inoculated into $10 \mathrm{~mL}$ of modified broth $(20.0 \mathrm{~g} / \mathrm{L}$ dextrose, $4.0 \mathrm{~g} / \mathrm{L}$ potato starch, $150 \mathrm{mg} / \mathrm{L} \mathrm{MG}$ ) (Barapatre et al., 2017) supplemented with $50 \mathrm{mg} / \mathrm{L}$ of chloramphenicol in order to avoid bacterial contamination (Chaijak et al., 2017). The growth potential was measured by a UV-Vis spectrophotometry (UV-1780, Shimadzu, Japan) at $600 \mathrm{~nm}$ according to the procedure described by Chaijak et al. (2018). The result was collected at 1, 2, 3, 4 and 5 days. The growth curve was developed by comparison with the standard curve. The $1 \mathrm{~mL}$ of the 5 -days old $G$. reessii $\left(1.0 \times 10^{7} \mathrm{cell} / \mathrm{mL}\right)$ 
in PDB (Sigma-Aldrich, United States) was inoculated into $9 \mathrm{~mL}$ of modified broth contained $150 \mathrm{mg} / \mathrm{L} \mathrm{MG}$. Then it was incubated at $30.0 \pm 1.0^{\circ} \mathrm{C}$ for 5 days without shaking. The MG degraded yeast Saccharomyces cerevisiae was used as control (Biradar et al., 2016).

Laccase activity was determined according to the modified method from Chaijak et al. (2018), at $436 \mathrm{~nm}$ using ABTS (2,2'-Azino-bis(3-ethylbenzothiazoline-6-sulphonic acid)) as a substrate (Sigma-Aldrich, United States). The mixture contained $1 \mathrm{mM}$ ABTS in $100 \mathrm{mM}$ sodium phosphate buffer (pH 4.8) mixed with $0.1 \mathrm{~mL}$ aliquots of crude enzyme in a total volume of $1.0 \mathrm{~mL}$. The laccase activity was monitored at 1,2,3,4 and 5 days. One unit of enzyme activity was defined as the amount of enzyme required to produce $1 \mu$ mole of oxidized ABTS per minute. The laccase activity $(\mathrm{U} / \mathrm{mL})$ was calculated as follows:

Laccase activity $=\frac{\left(\frac{\Delta A b s}{\text { mins }}\right) \times \text { total volume } \times 10^{6}}{\varepsilon \times \text { sample volume }}$ where $\Delta \mathrm{Abs}$ is the final absorbance - initial absorbance, and the is the extinction co-efficient $\left(29,300 \mathrm{~m}^{-1} \mathrm{~cm}^{-1}\right)$. The MG removal (Marco et al., 2019) was determined by UV-Vis spectrophotometry at $618 \mathrm{~nm}$ and was calculated as follows:

$$
M G \text { removal }=\left[\frac{A-B}{A}\right] \times 100
$$

where $\mathrm{A}$ is the initial absorbance, and $\mathrm{B}$ is the final absorbance. The experiments were performed in triplicate.

\section{MFC DESIGN AND OPERATION}

Figure 2 shows a schematically depiction of the new design of single chamber MFC. The acrylic cube with $100 \mathrm{~mL}$ working volume was used as the anode chamber, in which the four pieces of $3.0 \times 10.0 \mathrm{~cm}$ of plain carbon cloth (Fuel Cell Store, United States) were placed as the anode electrode. The four pieces of 3.0 $\times 10.0 \mathrm{~cm}$ of $0.5 \mathrm{mg} / \mathrm{cm}^{2}$ platinum $(\mathrm{Pt})$ coated carbon cloth (Fuel Cell Store, United States) were placed as the cathode electrode. The $3.0 \times 5.0 \mathrm{~cm}$ of ceramic

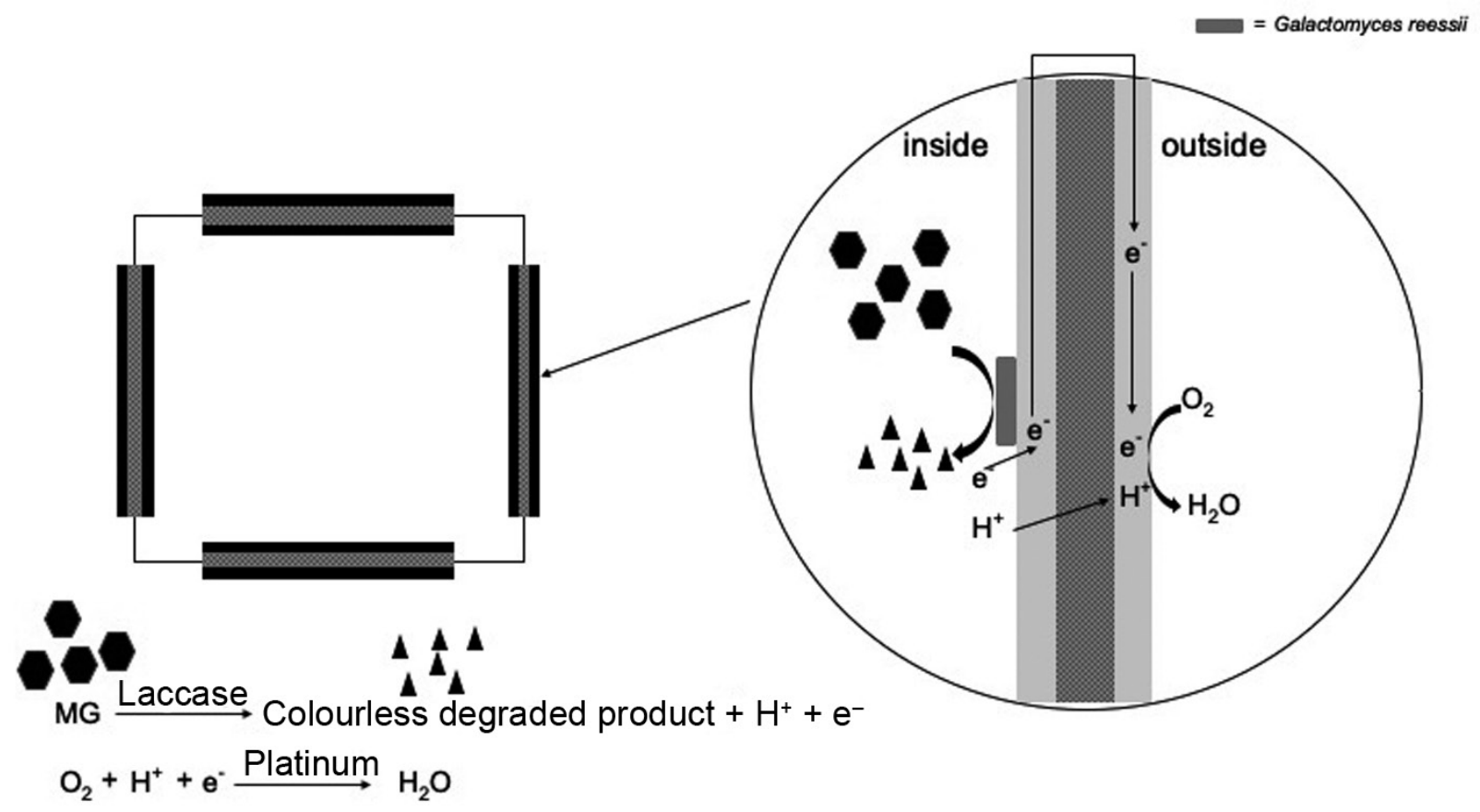

Fig. 2. A schematically depicts of the new design of multi-electrode single chamber MFC 
plate $(0.5 \mathrm{~cm}$ thickness) was used as proton exchange membrane (PEM), which was inserted between the electrodes to transport the proton $\left(\mathrm{H}^{+}\right)$. The open circuit voltage (OCV) was collected using the LabVIEW system engineering software (National Instruments, United States) every 10 minutes during the 5 days of operation. The closed circuit voltage (CCV) was determined at $1 \mathrm{~K} \Omega$. The current density $(\mathrm{CD})$ and power density (PD) were calculated as follows:

$$
\begin{aligned}
\mathrm{I} & =\mathrm{V} / \mathrm{R} \\
\mathrm{CD} & =\mathrm{I} / \mathrm{A}_{\mathrm{vol}} \\
\mathrm{P} & =\mathrm{I} \cdot \mathrm{V} \\
\mathrm{PD} & =\mathrm{P} / \mathrm{A}_{\mathrm{vol}}
\end{aligned}
$$

where $\mathrm{I}$ is the current $(\mathrm{mA}), \mathrm{V}$ is the $\mathrm{CCV}$ at $1 \mathrm{~K} \Omega$, $\mathrm{R}$ is the external resistance $(\mathrm{mV}), \mathrm{CD}$ is the current density $\left(\mathrm{A} / \mathrm{m}^{3}\right), \mathrm{A}_{\mathrm{vol}}$ is the working volume of the anode chamber $\left(\mathrm{m}^{3}\right), \mathrm{P}$ is the power $(\mathrm{mW})$, and $\mathrm{PD}$ is the power density $\left(\mathrm{W} / \mathrm{m}^{3}\right)$. The MG removal $(\%)$ was determined after 5 days of operation, as previously described.

\section{RESULTS AND DISCUSSION}

The MG dye is a generally applied in aquaculture such as fish farming, to treat protozoan and fungal diseases. Because of its toxicity, using the MG dye is prohibited in some countries. Some previous studies reported that the dye in question could be degraded and removed by some natural enzymes, such as fungal laccase (Yang et al., 2015).

In this study, the growth potential was measured by UV-Vis spectrophotometry at $600 \mathrm{~nm}$ for 5 days at $30 \pm 1.0^{\circ} \mathrm{C}$ under facultative anaerobic condition. The results showed that the yeast $G$. reessii can growth in modified broth supplemented with $150 \mathrm{mg} / \mathrm{L} \mathrm{MG}$. The growth potential of $G$. reessii in modified broth with $150 \mathrm{mg} / \mathrm{L} \mathrm{MG}$ was indicated by cell density (cell/ $/ \mathrm{mL}$ ) and showed in Figure 3, while the initial cell density was $0.1 \times 10^{7} \mathrm{cell} / \mathrm{mL}$. The results indicated that the G. reessii could grow rapidly, as much as 5 -fold, in MG-containing medium compared with control S. cerevisiae when they were incubated for 24 hours. The growth potential increased to 8-fold and 10-fold higher than the control, when the samples were cultured for 48 hours and 72 hours, respectively.

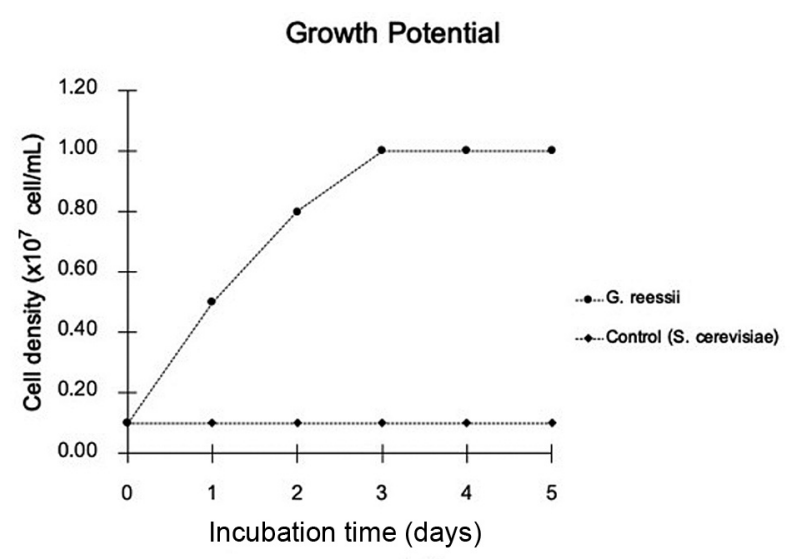

Fig. 3. The growth potential of $\mathrm{G}$. reessii in modified broth with $150 \mathrm{mg} / \mathrm{L} \mathrm{MG}$ when it was incubated at $30 \pm 1.0{ }^{\circ} \mathrm{C}$ under facultative anaerobic condition for 5 days

For laccase activity determination, the $10 \%(\mathrm{v} / \mathrm{v})$ of 5-days old termite-associated yeast G. reessii $(1 \times$ $10^{7}$ cell $\left./ \mathrm{mL}\right)$ in the PDB was inoculated into $90 \%(\mathrm{v} / \mathrm{v})$ modified media supplemented with $150 \mathrm{mg} / \mathrm{L} \mathrm{MG}$, and incubated at $30 \pm 1.0^{\circ} \mathrm{C}$ under facultative anaerobic conditions for 5 days. The incubated media was centrifuged at $12,000 \mathrm{rpm}$ for 10 minutes to separate an extracellular crude enzyme for the cell pellets. The laccase activity was monitored at $436 \mathrm{~nm}$ using ABTS assay and calculated according to the formula established in the previous study by Chaijak et al. (2018). The extracellular laccase activity was showed in Figure 4, in which the S. cerevisiae was used as control.

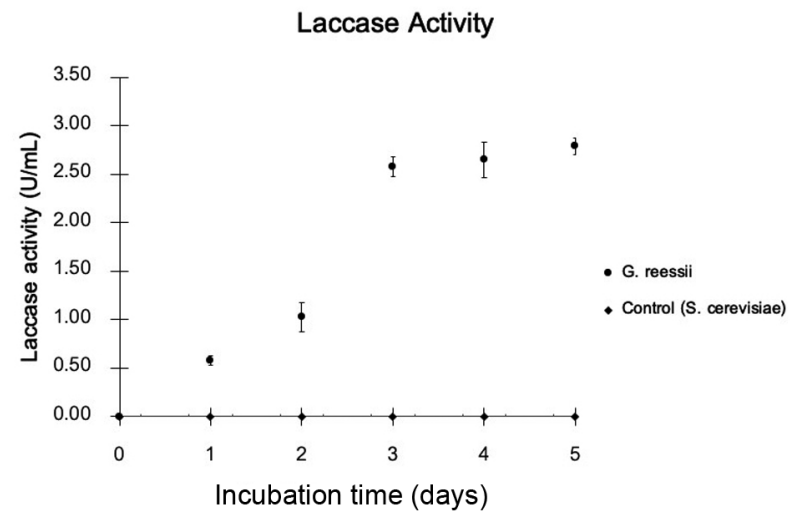

Fig. 4. The laccase activity $(\mathrm{U} / \mathrm{mL})$ of $\mathrm{G}$. reessii in modified broth with $150 \mathrm{mg} / \mathrm{L} \mathrm{MG}$ when it was incubated at $30 \pm 1.0{ }^{\circ} \mathrm{C}$ under facultative anaerobic condition for 5 days 
The laccase activity of termite-associated yeast $G$. reessii was $0.58 \pm 0.05,1.03 \pm 0.15,2.58 \pm 0.10,2.65$ \pm 0.18 and $2.79 \pm 0.09 \mathrm{U} / \mathrm{mL}$ from day- 1 to day- 5 respectively, whereas no laccase activity of $S$. cerevisiae was detected.

In the in vitro decolourisation, the supernatant was collected from the previous section. The maximum MG removal by the termite-associated yeast $G$. reessii of $88.93 \pm 1.00 \%$ was obtained after 5 -days incubation. The MG removal of $G$. reessii was $96.37 \%$ higher than control S. cerevisiae $(3.23 \pm 0.99 \%)$. The MG decolourisation was showed in Figure 5. There was no $\mathrm{pH}$ adjustment or change in other conditions, just the enzyme purification method was used.

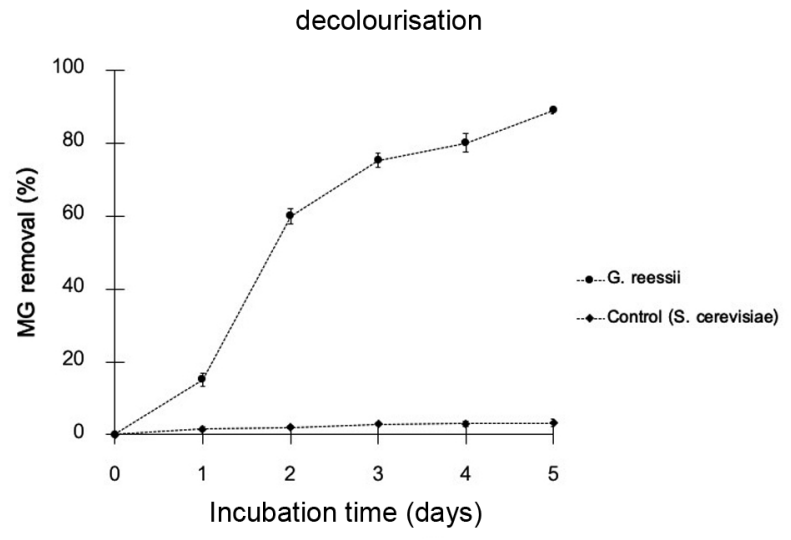

Fig 5. MG removal (\%) of G. reessii in modified broth with $150 \mathrm{mg} / \mathrm{L} \mathrm{MG}$ when it was incubated at $30 \pm 1.0{ }^{\circ} \mathrm{C}$ under facultative anaerobic condition for 5 days

On the other hand, the various members of fungi kingdom were used for MG biological treatment. For instance, some previous studies used filamentous fungi for MG removal. Yang et al. (2017) used a cross-linked laccase of fungus Cerrena sp. HYB07 with chitosan for MG removal. They found that this cross-linked enzyme was able to remove $\mathrm{MG}$ at $60^{\circ} \mathrm{C}$ in $90 \%$. In MG removal using laccase from Trichoderma asperellum, Shanmugam et al. (2017) reported 91.18\% MG removal under the optimum condition with the enzyme concentration of $1.5 \mathrm{Unit} / \mathrm{mL}, \mathrm{pH}$ 6.7, MG concentration of $122.66 \mathrm{mg} / \mathrm{L}$, and the incubation time of 98.58 minutes, whereas Barapatre et al. (2017) showed the removal of MG using a high poten- tial ligninolytic fungus Aspergillus flavus strain F10. The latter completely removed the MG (in the initial concentration of $150 \mathrm{mg} / \mathrm{L}$ ) within 8 days, when inoculated into Kirk's basal media and with $\mathrm{pH}$ adjusted at 5.8. The use of medical mushroom for MG degradation was reported, for instance: one study (Morales-Alvarez et al., 2017) used a ligninolytic enzyme, such as laccase of Lingzhi mushroom or Genoderma lucidum for $10 \mathrm{mg} / \mathrm{L}$ of $M G$ removal. The results showed that the biological process was able to remove $\mathrm{MG}$ in $90 \%$ when supplemented with exogenous cultural medium, glucose. In terms of using yeast, Biradar et al. (2016) inoculated the yeast Saccharomyces cerevisiae to 100 $\mathrm{mg} / \mathrm{L}$ MG. The removal was reported at $99 \%$ when supplemented with $1 \mathrm{mg} / \mathrm{mL}$ ethanolic extracts of the plants Boerhaavia diffusa, Terminalia chebula, and Clitoria ternatea.

There are reports that some azo dyes such as MG and thionin can be used as electron shuttles to simulate wastewater decolourisation and bio-electricity generation in MFC (Chen et al., 2014), but no previous report explained the organization or treatment process of MG in the context of MFC technology. In this work, the novel design of yeast-immobilized MFC was developed to improve MG removal and bio-electricity generation. At first stage, the 10\% (v/v) of 5-days old termite-associated yeast G. reessii $\left(1 \times 10^{7} \mathrm{cell} / \mathrm{mL}\right)$ in the PDB was inoculated into the anode chamber that was filled with the $90 \%(\mathrm{v} / \mathrm{v})$ modified media, supplemented with $150 \mathrm{mg} / \mathrm{L} \mathrm{MG}$, and incubated under facultative anaerobic conditions for 5 days for yeast immobilization on the anode electrode surface. Then the anolyte was fed out, and immediately fed with fresh modified broth at $150 \mathrm{mg} / \mathrm{L}$ MG. The OCV was collected every 10 minutes until 1 cycle of MFC was achieved. The results revealed that the novel multi-electrode MFC reached 1 cycle within 24 hours, the experiment was carried out in 3 times' replication in order to make sure that the multi-electrode MFC was able to generate the electrical power using MG contained media (see: Fig. 6). The $1 \mathrm{~K} \Omega$ resistor was connected between the electrodes in order to achieve the CCV. The maximum OCV of $550.0 \pm 10.0 \mathrm{mV}$ and the $\mathrm{CCV}$ of $390.0 \pm 10.0 \mathrm{mV}$ were obtained. The CD and PD were calculated by comparing with the working volume $\left(0.0001 \mathrm{~m}^{3}\right)$. The CD and $\mathrm{PD}$ of $3.90 \pm 0.10 \mathrm{~A} / \mathrm{m}^{3}$ and $1.52 \pm 0.08 \mathrm{~W} / \mathrm{m}^{3}$ were 


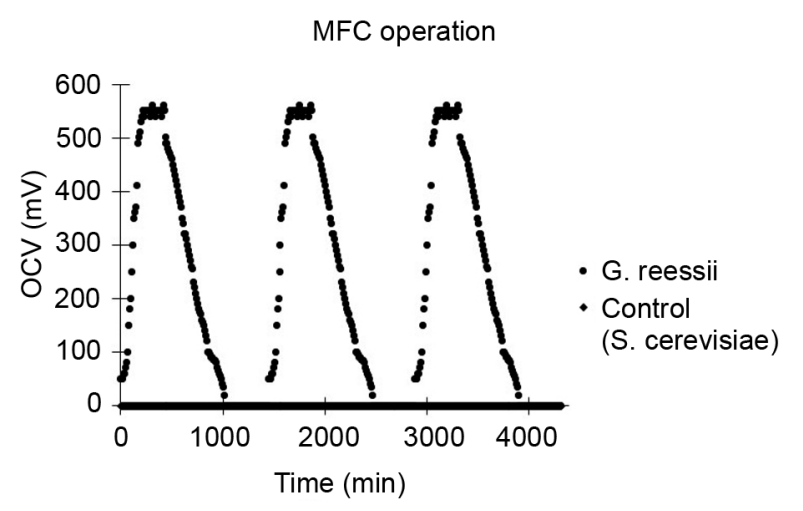

Fig. 6. The open circuit voltage of G. reessii in modified broth with $150 \mathrm{mg} / \mathrm{L} \mathrm{MG}$ in novel multi-electrode MFC

achieved. Moreover, after 24 hours, the MG removal of novel multi-electrode MFC operation was at the level of $93.15 \pm 0.92 \%$. The result indicated the novel multi-electrode MFC can remove the MG five times more quickly than in vitro removal. No electrical energy was gained by control (S. cerevisiae on an anode electrode).

Alternatively, Long et al. (2017) developed a novel parallel circuit MFC photo-electrocatalytic cell (MFCPEC) combined system to enhance azo dye removal. Their results indicated this system could be used for azo dye removal with $85 \%$ efficiency. Moreover, some works combined a MFC system with wetland to remove an azo dye, and they found that in optimal conditions, the MFC system could remove a toxic dye, and generate high voltage potential (Fang et al., 2017). No previous work explained a single use of MFC system for MG removal.

\section{CONCLUSIONS}

The novel MFC multi-electrode with a yeast-immobilized anode achieved $98.15 \pm 0.92 \%$ colour removal of azo dye MG in 1 day of operation, and outperformed control MFC with respect to OCV potential. The maximum OCV of $550.0 \pm 10.0 \mathrm{mV}$ and the CCV of $390.0 \pm 10.0 \mathrm{mV}$ were obtained. The $\mathrm{CD}$ and $\mathrm{PD}$ of $3.90 \pm 0.10 \mathrm{~A} / \mathrm{m}^{3}$ and $1.52 \pm 0.08 \mathrm{~W} / \mathrm{m}^{3}$ were achieved. After treatment in MFC, the MG removal was rapid: 5-times quicker than direct inoculation with laccase producing yeast $G$. reessii in MG solution. Therefore, the system could have the potential for treatment of high concentration MG contaminated wastewater, and produce a bioelectric energy.

\section{ACKNOWLEDGEMENT}

The author would like to thank Professor Dr. Chikashi Sato and Miss Noris Paucar, Department of Civil and Environmental Engineering, College of Science and Engineering, Idaho State University, United States for their valuable suggestions.

\section{REFERENCES}

Asgher, M., Shahid, M., Kamal, S., Iqbal, H.M.N. (2014). Recent trends and valorization of immobilization strategies and ligninolytic enzymes by industrial biotechnology. J. Mol. Catal. B-Enzym., 101(1), 56-66.

Ba, S., Arsenault, A., Hassani, T., Jones, J.P., Cabana, H. (2013). Laccase immobilization and insolubilization: from fundamentals to applications for the elimination of emerging contaminants in wastewater treatment. Crit. Rev. Biotechnol., 33(1), 404-418.

Barapatre, A., Aadil, K.R., Jha, H. (2017). Biodegradation of malachite green by the ligninolytic fungus Aspergillus flavus. Clean-Soil. Air. Water., 45, 1-12.

Bergwerff, A.A., Scherpenisse, P. (2003). Determination of residues of malachite green in aquatic animals. J. Chromatogr. B., 788, 351-359.

Biradar, S.P., Rane, N.R., Patil, T.S., Khandare, R.V., Govinwar, S.P., Pawar, P.K. (2016). Herbal augmentation enhances malachite green biodegradation efficacy of Saccharomyces cerevisiae. Biologia., 71, 475-483.

Cha, C.J., Doerge, D.R., Cerniglia, C.E. (2001). Biotransformation of malachite green by the fungus Cunninghamella elegans. Appl. Environ. Microb., 67, 4358-4360.

Chaijak, P., Lertworapreecha, M., Sukkasem, C. (2017). Screening of laccase producing fungi from mould-building termite in Phatthalung province, Southern of Thailand. Res. J. Biotechnol., 12, 70-72.

Chaijak, P., Lertworapreecha, M., Sukkasem, C. (2018). Phenol removal from palm oil mill effluent using Galactomyces reessii termite-associated yeast. Pol. J. Environ. Stud., 27, 39-44.

Chen, B.Y., Xu, B., Qin, L.J., Lan, J.C.W., Hsueh, C.C. (2014). Exploring redox-mediating characteristics of textile dye-bearing microbial fuel cells: thionin and malachite green. Bioresour. Technol., 169, 277-283.

Comelius, M.L., Daigle, D.J., Connick, W.J., Parker, A., Wunch, K. (2002). Responses of Coptotermes formosa- 
nus and Reticulitermes flavipes (Isoptera: rhinotermitidae) to three types of wood rot fungi cultured on different substrates. J. Econ. Entomol., 95(1), 121-128.

Fang, Z., Cao, X., Li, X.X., Wang, H., Li, X.N. (2017). Electrode and azo dye decolorization performance in microbial fuel cell coupled constructed wetlands with different electrode size during long-term wastewater treatment. Bioresour. Technol., 238, 450-460.

Fernandez, M., Sanroman, M.A., Moldes, D. (2013). Recent developments and applications of immobilized laccase. Biotechnol. Adv., 31(1), 1808-1825.

Kalyani, D.C., Patil, P.S., Jadhav, J.P., Govindwar, S.P. (2008). Biodegradation of reactive textile dye Red BLI by an isolated bacterium Pseudomonas sp. SUK1. Bioresour. Technol. 99, 4635-4641.

Kudanga, T., Le Rose-Hill, M. (2014). Laccase applications in biofuels production: current status and future prospects. Appl. Microbiol. Biot., 98(1), 6525-6542.

Long, X.Z., Pan, Q.R., Wang, C.Q., Wang, H., Li, H., Li, X.N. (2017). Microbial fuel cell-photoelectrocatalytic cell combined system for the removal of azo dye wastewater. Bioresour. Technol., 244, 182-191.

Marco, de C., Mauler, R. S., Daitx, T. S., Krindges, I., Cemin, A., Bonetto, L. R., Crespo, J. S., Carli, L. N., Giovanela, M. (2019). Removal of malachite green dye from aqueous solutions by a magnetic adsorbent. Sep. Sci. Tecnol., 55, 1-13.

Morales-Alvarez, E.D., Rivera-Hoyos, C.M., Chaparro-Nunez, L.E., Daza, C.E., Poutou-Pinales, R.V., Pedroza-Rodriguez, A.M. (2017). Decolorization and detoxification of malachite green by Ganoderma lucidum: Key operating parameters and adsorption studies. J. Environ. Eng., $143,1-12$

Pezzella, C., Guatino, L., Piscitelli, A. (2017). How to enjoy laccases. Cell Mol. Life. Sci., 72(1), 923-940.

Rozendal, R.A., Hamelers, H.V.M.,Rabaey, K., Keller, J., Buisman, C.J.N. (2008). Towards practical implementa- tion of bioelectrochemical wastewater treatment. Trends. Biotechnol., 26, 450-459.

Senanayake, P.D., Mohotti, K.M., Paranagama, P.A. (2016). Identification and substrate utilization of fungi associated with low country live wood termite, Glyptotermes dilatatus Bugnion \& Popoff and the host plant, Camellia sinensis LO Kuntze. J. Natl. Sci. Found. Sri., 44(1), 175-184.

Shanmugam, S., Ulaganathan, P., Swaminathan, K., Sadhasivam, S., Wu, Y.R. (2017). Enhanced biodegradation and detoxification of malachite green by Trichoderma asperellum laccase: Degradation pathway and product analysis. Int. Biodeter. Biodegr., 125, 258-268.

Srivastava, S., Sinha, R., Roy, D. (2004). Toxicological effects of malachite green. Aquat. Toxicol., 66, 319-329.

Taprab, Y., Ohkuma, M., Johjima, T., Maeda, S., Moriya, S., Inoue, T., Suwanarit, P., Noparatnaraporn, N., Kudo, T. (2002). Molecular phylogeny of symbiotic basidiomycetes of fungus-growing termites in Thailand and their relationship with the host. Biosci. Biotech. Bioch., 66(1), 1159-1163.

Yang, J., Li, W.J., Ng, T.B., Deng, X.Z., Lin, J., Ye, X.Y. (2017). Laccases: production, expression regulation, and applications in pharmaceutical biodegradation. Front. Microbiol., 8(1), 1-24.

Yang, J., Yang, X.D., Lin, Y.H., Ng, T.B., Lin, J., Ye, X.Y. (2015). Laccase catalyzed decolorization of malachite green: Performance optimization and degradation mechanism. Plos. One., 10, 1-14.

Zhang, C., Zhang, S., Diao, H.W., Zhao, H.Z., Zhu, X.Y., Lu, F.X., Lu, Z.X. (2013). Purification and characterization of a temperature and $\mathrm{pH}$ stable laccase from the spores of Bacillus vallismortis fmb-103 and its application in the degradation of malachite green. J. Agr. Food. Chem., 61, 5468-5473.

\section{USUWANIE ZIELENI MALACHITOWEJ I WYTWARZANIE BIOELEKTRYCZNOŚCI Z WYKORZYSTANIEM MIKROBIOLOGICZNEGO OGNIWA PALIWOWEGO W KONFIGURACJI WIELOELEKTRODOWEJ}

\section{ABSTRAKT}

\section{Cel pracy}

Zieleń malachitowa (MG) jest dobrze znanym syntetycznym barwnikiem, którego roztwór wodny jest stosowany jako środek farmaceutyczny do zwalczania chorób pierwotniakowych i grzybiczych. Barwnik ten może ulegać fermentacji, przekształcając się w szkodliwy kancerogen, zieleń leukomalachitową, metabolit uwalniany do strumienia wody przez florę. 


\section{Materiały i metody}

W ramach przedstawionych tu badań opracowano nowatorski projekt mikrobiologicznego ogniwa paliwowego (MFC) do usuwania MG poprzez unieruchomienie lakazy drożdży Galactomycess reessii na elektrodzie anodowej.

\section{Wyniki i wnioski}

Wyniki pokazały, że z powodzeniem usunięto około $98,15 \pm 0,92 \%$ MG w ciągu 1 dnia działania ogniwa, podczas gdy bezpośrednia inokulacja może usunąć z $88,93 \pm 1,00 \%$ po 5 dniach. Ponadto uzyskano napięcie obwodu otwartego (OCV), gęstość prądu (CD) i gęstość mocy (PD) na poziomie 550,00 $\pm 10,00 \%, 3,90 \pm$ $0,10 \mathrm{~A} / \mathrm{m}^{3}$ i $1,52 \pm 0,08 \mathrm{~W} / \mathrm{m}^{3}$. Badanie wykazało, że nowatorski projekt MFC wykazuje duży potencjał do usuwania MG i wytwarzania bioelektryczności. Niniejsza praca jest pierwszym doniesieniem o użyciu drożdży symbiotycznych z termitami do usuwania syntetycznego barwnika.

Słowa kluczowe: czynnik rakotwórczy, drożdże, oksydoreduktaza, lakaza, mikrobiologiczne ogniwo paliwowe 